\title{
THE WORKING ACTIVITY IN THE MANIFESTATIONS OF SPECIFICATIONS OF MONEY ATTITUDE AND ITS PERCEPTION
}

\author{
Hayrapetyan D. R. (Yerevan State University, Yerevan, Armenia) \\ davidhaiarm@ysu.am
}

Amiraghyan A.V. (Yerevan State University, Yerevan, Armenia)

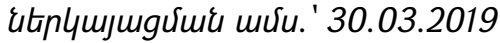

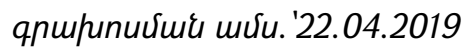

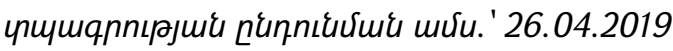

People greatly differ in their perception of money and money attitude. According to different researches they are formed under the influence of certain factors, among which have been separated and studied the following ones: person's age, gender, personal and socio-cultural peculiarities, person's income level etc. Each of these factors forms certain standpoints towards money. As the main means of acquiring money is considered to be the work, in this research we have studied person's work performance in the manifestation of money attitude and its perception specifications. Moreover, the aspiration for acquiring money is especially obvious in today's youth. So this article is directed to do a research about the money attitude and its perception specifications among the young students who either have or have not a working activity.

Key words: financial behavior, labor activity, money attitude, money perception.

\section{Theoretical analysis of the issue}

In the modern world money has become a tool for people not only for satisfying their biological needs, but also a tool to gain power, authority and a higher social status. It can also be the reason for displaying anxiety, distrust and saving behavior. All these and other problems are the subject of study in the psychology of money but according to Furnham and Argyle the psychology of money is one of the most neglected topics in the whole discipline of psychology. They state that economists are interested in aggregated data at the macro level how classes, groups and countries use, spend and save their money under certain conditions and to this extent they have more in common with sociologists than with psychologists who are interested in individual and small group differences. Whereas individual differences are "error variance" for the economists, they are the "stuff" of psychology [3].

Among the main factors influencing the money attitude the researchers have separated the following ones: gender, age, socio - cultural peculiarities, the 
person's income level and several personal specifications etc. It is found out that young people are more inclined to use money to influence other people and they are less concerned about financial security and financial future than older people (Furnham, 1984). As for gender differences, it has been found out that males are more confident in their financial matters, they are more satisfied with their financial condition and are more optimistic about their future financial condition as compared to females [1, p. 71].

Many studies confirm interrelation of money attitudes with the level of income. Furnham states that obsession with money is more typical of people with lower level of income and they also tend to use money as a means to gain power over other people [2]. In accordance with the results of the cross-cultural study conducted in 43 countries in more economically developed countries people consider money to be less important and the poorer the country is, the more concerned people are about the money [3, p. 332]. However, Yamauchi and Templer have revealed that money attitudes practically do not depend on the level of income [8].

According to scientists employment provides five categories of psychological experience that promote mental well-being: time structure (an absence of time structure can be a major psychological burden), social contact, collective effort and purpose (employment offers a social context outside the family), social identity (employment is an important element in defining oneself), regular activity (organizing one's daily life) [5].

So people being unemployed can feel the lack of those five categories of psychological experience which are already mentioned above. But it is stated that there is a difference between long - term and short - term unemployment: longterm unemployment has large negative effects on mental health, while short-term unemployment does not harm it significantly. They have also found out that those with more education suffer a larger emotional penalty for being long-term unemployed [4]. Thus the work performance becomes on the one hand a guarantee to secure stable income and on the other hand is one of the main factors for the mental welfare.

Having as basis the approach made by Yamauchi and Templer that the money attitude scales practically don't depend on the person's income, a question arises on whether or not the work performance influences on the money perception and money attitude.

\section{Experimental design of the research}

Based on the existing studies there is a necessity to examine the work performance in the manifestation of money attitude and its perception specifications. It is supposed that money is manifested as a hardened tool for the financial behavior, that is gifted with a stable perception and evaluation and the attitude towards it is not connected by the factor of the existing work. For this 
research we have chosen the questionnaire "Money Attitude Scale" processed by K. Yamauchi and D. Templer [8], the money perception semantic differential method [6] and a questionnaire processed by us to receive working and social-demographic information about the person under the research (See Appendix).

Money Attitude Scale is represented by 4 factors (Power - prestige, Retention - time, Anxiety, Distrust). Items loading highly on Power - Prestige all pointed to the use of money to impress and influence others and as a symbol of success. Items loading highly on Retention - time factor describe behaviors aimed at the future which require planful preparation. A high scoring person on Distrust is prone to maintain suspicious and doubtful attitudes, while a low scorer is viewed as trusting and accepting of situations involving money. Persons scoring high on Anxiety could be described as believing that money is a source of anxiety and a source of protection from it. By contrast, low scorers could be described as less anxious with money and in money situations [8].

The money perception semantic differential method consists of 25 signifiers: valuable, significant, necessary, independent, heavy, strong, thick, rough, clean, achievable, nice, constructive, well, comfortable, helpful, difficult, motivating, beloved, productive, realizable, famous, irreplaceable, permanent, invariable, secure and the opposite: inflated, unsignificant, unnecessary, depending, light, weak, thin, fine, dirty, inaccessible, unpleasant, not constructive, not wealthy, uncomfortable, ineffective, easy, not motivating, not beloved, ineffective, not realizable, unknown, replaceable, temporary, changeable, dangerous [6]. During the experiment money has been evaluated by these 25 signifiers in the scale -3 to 3 .

The questionnaire processed by us is aimed to get some information about gender, age, person's employment, financial state, about the desire of finding a job and making practical steps for it.

The research group consisted of 75 students aged 18-23, 29 of which were male and 46 female representatives. Each researched group (presently the employees, previously the ones who had been employed and who had never worked) consisted of 25 people who were on a survey. The choice of the research group is connected to the fact that in that group the representatives of the three subgroups are presented. The majority of the students allocate their time to the studying process and they obtain the necessary amount of money not by working but by being supported by their families (although the majority of the unemployed, despite their financial state, have a desire to work).

In our opinion the listed peculiarities will allow us to figure out if the fact of being in a working performance influences the young students' money perception and the attitude towards it. 


\section{The explanation and the analysis of the results}

Through the analysis of the research results it turned out that between the 3 research groups (the present employees, previously employed ones and the ones who have never been employed) there are no significant differences connected with the money perception and towards its attitude manifestation (Power - prestige: Levene's $p=.198$, ANOVA $p=.543$; Retention - time: Levene's $p=.516$, ANOVA $\mathrm{p}=.372$; Distrust: Levene's $\mathrm{p}=.279$, ANOVA $\mathrm{p}=.616$; Anxiety: Levene's $\mathrm{p}=.956$, ANOVA $\mathrm{p}=.881$ ), (Fig 1.)

Thus we can suppose that people who have ever dealt with money despite the fact whether they have earned it while working or their family or their parents gave it to them, do not differ much from each other in their perception and standpoint. The money essentially being presented as a conventional means for the financial and commercial relations manifests itself as a hardened tool for the financial behavior gifted by a stable perception and evaluation. The necessity to work and the factor for making practical steps for finding a job do not significantly influence the money perception and the formation of its attitude.

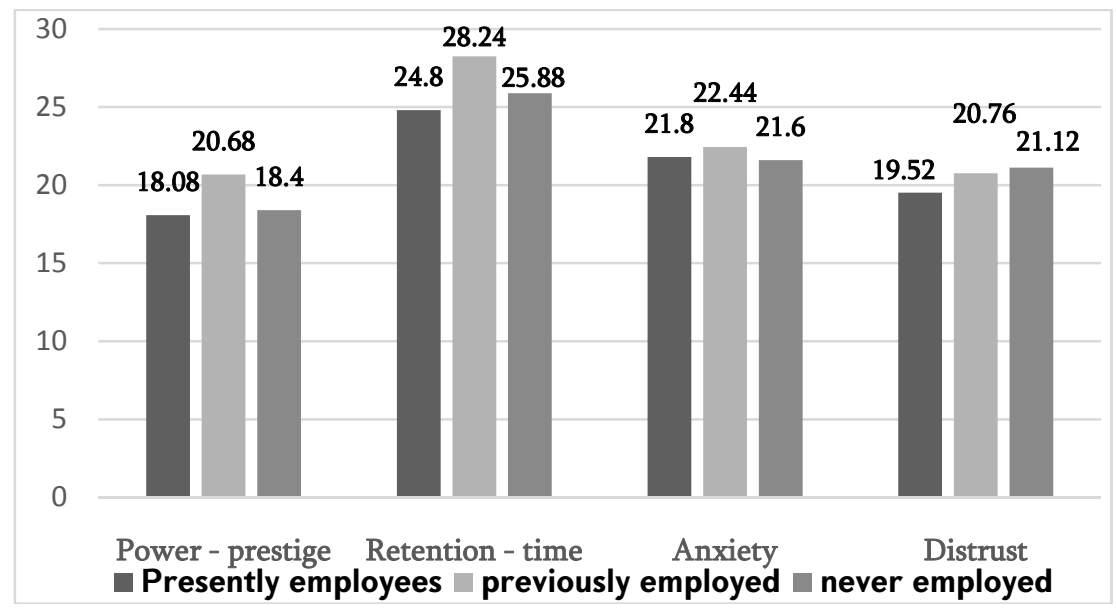

Fig. 1. Results of the money attitude scale in the three experimental groups

The received results testify that the ones who lack the desire to find a job have lower result in the "Distrust" scale than the ones who burn with this desire to find one (Levene's $p=.033, U$ Mann - Whitney $p=.010$ ) Among the ones who lack the desire to find a job, unlike the ones who long for a one, the "Anxiety" scale is low (Levene's $p=.030$, U Mann - Whitney $p=.050$ ).

As we have already mentioned, work has an importance in providing both financial and mental welfare. So, the desire of finding a job can be connected with the satisfaction of the need to live comfortably. When a person does not have a job, but wants to work, the need of mental and financial welfare is not satisfied. Thus 
the ones who wish to find a job perform a great deal of fluctuation and incredulity while appearing in circumstances connected with money issues $(M=21,57)$. And on the contrary the ones who lack the desire to find a job perform credibility and accept the circumstances connected with money the way they are $(M=15)$. The ones who lack to find a job can be described as people who perform less disturbance and trepidation towards money and the circumstances connected with it $(M=17)$. And the ones who desire to find a job are more inclined to the standpoint that money is a source of anxiety, as well as a source of protection from it $(M=22,55)$.

Several peculiarities were withdrawn concerning money perception and attitude due to gender. The girls in the "Retention - time" scale perform much higher results than boys (Levene's $p=.742$, T-test $p=.009$ ). This supposes that the girls give a great significance to preparation and provision in the future $(M=28,39)$ rather than boys $(M=23)$.

Females despite the males recorded much lower results in money perception measurement signifiers such as "Achievable" (Levene's $p=.036$, U Mann-Whitney $\mathrm{p}=.042$ ), "Nice" (Levene's $\mathrm{p}=.302$, T-test $\mathrm{p}=.035$ ) and "Productive" (Levene's $p=.135$, T-test $p=.026)$. The boys evaluate the money to be more available, nice and productive than girls (Fig.2).

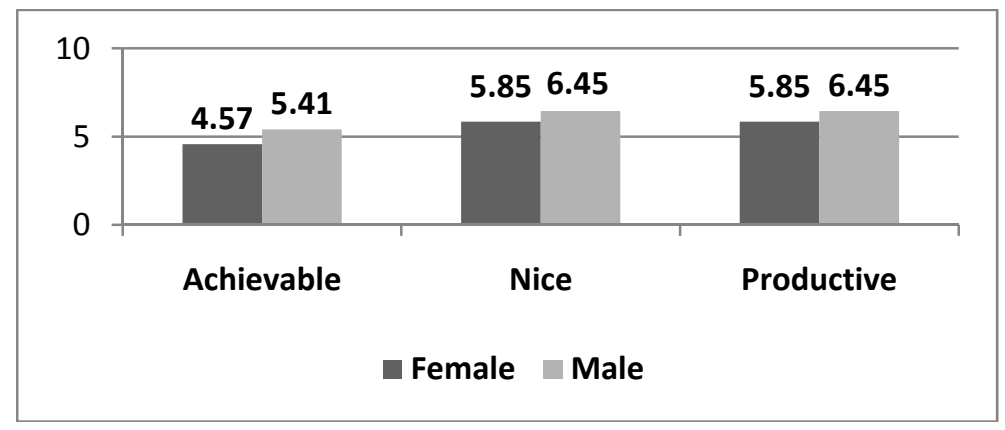

Fig. 2 Gender differences in money perception measurement signifiers

Gender differences in money attitude have been studied by many researchers. This differences are more obvious when they refer to a secure future planning. For example it is found out that $93.8 \%$ of the female respondents seemed very worried about not being able to save for old age compared to $87.9 \%$ of the males [7]. According to the results of our study males, unlike females, in terms of a financial behavior are more concentrated on the present and they do not worry about the future that much. This can be connected with the circumstance that males have less difficulties in finding a job and devoting their lives to their career than females. Besides, in many societies females do not have the financial independence, that males have. So money is qualified as more available, productive and nice by males, than by females. 
During the research it turned out that there is a negative correlation between the training course and the "Difficult" characterization ( $r=-.245, p=.034)$. In the more senior course the person studies, the less he perceives money as difficult. Such difference can be explained with the fact, that in the senior course the pofessional knowledge, skills and the higher level of professional competence let the students perceive money as less "difficult".

In this research we have tried to study the manifestation of connection between work performance and money attitude and its perception among the young students, who either have or don't have working performance. We can apply the results to young students. But here a question may arise, which kind of results we may get, if the research is conducted with the people, for whom the work performance is the main type of activity. As we have already mentioned, long term and short - term types of unemployment have different degrees of influence on mental health. Thus, the peculiarities of money attitude and its perception are not studied also for long-term and short-term unemployment.

\section{Conclusions}

1. The money essentially being presented as a conventional means for the financial and commercial relations manifests itself as a hardened tool for the financial behavior gifted by a stable perception and evaluation. The necessity to work and the factor for making practical steps for finding a job do not significantly influence the money perception and the formation of its attitude. So the work performance doesn't significantly effect on the money perception and money attitude. Thus we can suppose that people who have ever dealt with money despite the fact whether they have earned it while working or their family or their parents gave it to them, do not differ much from each other in their perception and standpoint.

2. The ones who wish to find a job perform a great deal of fluctuation and incredulity while appearing in circumstances connected with money issues, and on the contrary the ones who lack the desire to find a job perform credibility and accept the circumstances connected with money the way they are. The ones who lack to find a job can be described as people who perform less disturbance and trepidation towards money and the circumstances connected with it, and on the contrary the ones who desire to find a job are more inclined to the standpoint that money is a source of anxiety, as well as a source of protection from it. So, the desire of finding a job can be connected with the satisfaction of the need to live comfortably. When a person does not have a job, but wants to work, the need of mental and financial welfare is not satisfied.

3. The girls give a great significance to preparation and provision in the future rather than boys. The boys evaluate the money to be more available, nice and productive than girls. Such difference can be explained with the circumstance, 
that in many societies males have less difficulties in finding a job and devoting their lives to their career than females and also females do not have the financial independent that males have.

4. In the more senior course the person studies, the less he perceives money as "difficult". This can be connected with the fact that senior students have more professional knowledge, skills and higher level of professional competence. So this circumstance let them perceive money as less "difficult".

\section{References}

1. Семенов М.Ю. (2004), Особенности отношения к деньгам людей с разным уровнем личностной зрелости: дис. ... канд. филос. наук. Ярославль, - 178 с.

2. Furnham Adrian (1984), Many sides to the coin: the psychology of money usage, "Personality and Individual Differences" 5 (5) - 501-509 pp.

3. Furnham Adrian \& Argyle Michael (1998), The Psychology of Money, USA and Canada, published by Routledge, - $344 \mathrm{p}$.

4. Goldsmith A. \& Diette T. (2012), Exploring the link between unemployment and mental health outcomes, - American Psychological Association http://www.apa.org/pi/ses/resources/indicator/2012/04/unemployment.aspx

5. Harnois G. \& Gabriel Ph. (2000) Mental health and work: Impact, issues and good practices - Geneva, World Health Organization and the International Labour Organisation, $67 \mathrm{p}$.

6. Hayrapetyan D. (2015) Money and currency perception in the financial behavior of economic agent. Proceedings. Vth International Scientific Conference "The Current Issues In Theoretical and Applied Psychology" Yerevan, Armenia, October 23-25, pp. 637-640

7. Mohamad Fazli Sabri, Hayhoe, C.R. \& Igoh Lay Ai Attitudes, Values and Belief Towards Money: Gender and Working Sector Comparison (2006) Pertanika J. Soc. Sci. \& Hum. 14(2): Universiti Putra Malaysia Press - 121130pp.

8. Yamauchi K., Templer D. (1982) The development of a money attitude scale // J. of Personality Assessment. № 46. pp. 522-528pp.

\section{ТРУДОВАЯ ДЕЯТЕЛЬНОСТЬ В ПРОЯВЛЕНИЯХ ОСОБЕННОСТЕЙ ОТНОШЕНИЯ К ДЕНЬГАМ И К ИХ ВОСПРИЯТИЮ}

Айрапетян Д. Р. (Ереванский Государственный Университет, Ереван, Армения)

Амирагян А. В. (Ереванский Государственный Университет, Ереван, Армения) 
Люди значительно различаются по восприятию денег и по отношению к деньгам. Согласно различным исследованиям, восприятие денег и отношение к деньгам формируется под влиянием определенных факторов, среди которых были выделены и изучены следующие: возраст, пол, личные и социокультурные особенности, уровень доходов человека и т. д. Каждый из этих фракторов формирует определенные установки по отношению к деньгам. Поскольку основным средством получения денег считается работа, в этом исследовании мы изучили трудовую деятельность в проявлении отношений к деньгам и особенностей его восприятия. Так как стремление получить деньги особенно очевидно у современной молодежи, эта статья посвящена исследованию отношения к деньгам и его восприятия среди студентов, занимающихся и не занимающихся трудовой деятельностью.

Ключевые слова: финансовое поведение, трудовая деятельность, отношение к деньгам, восприятие денег.

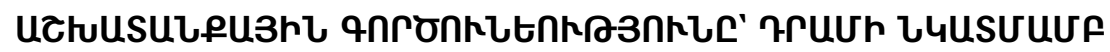

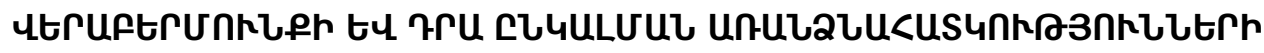 qrutunกחruttrnkU}

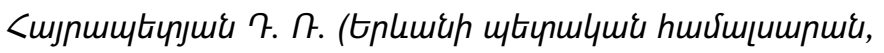

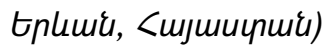

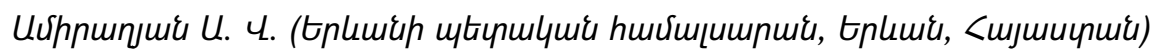

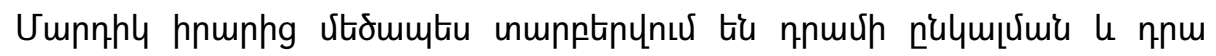

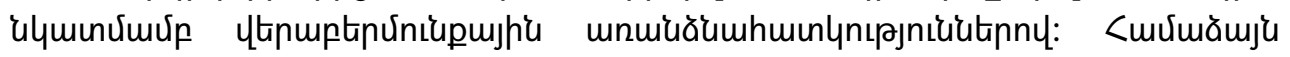

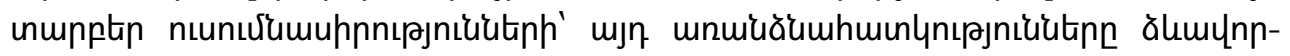

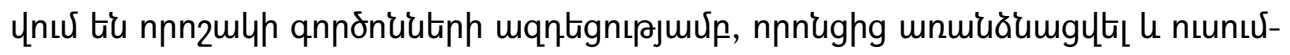

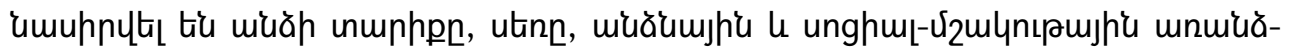

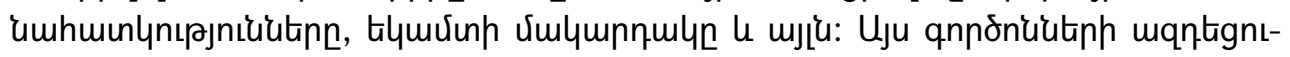

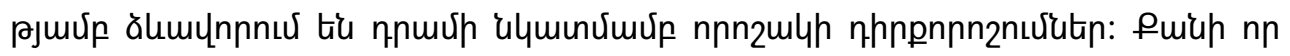

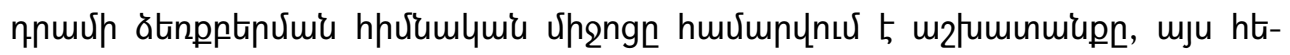

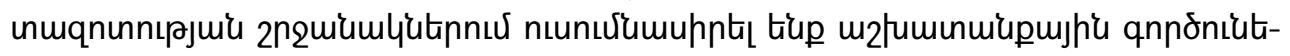

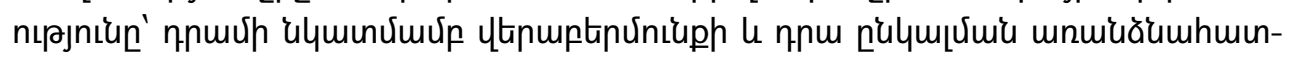

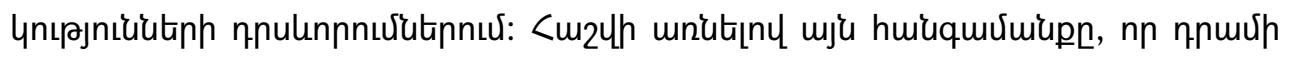

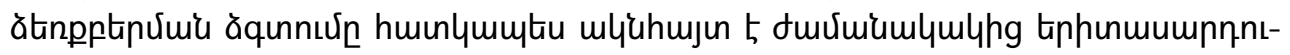

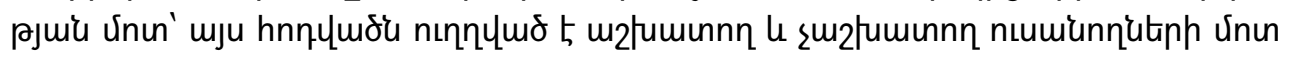

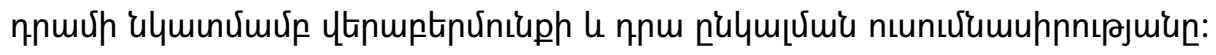

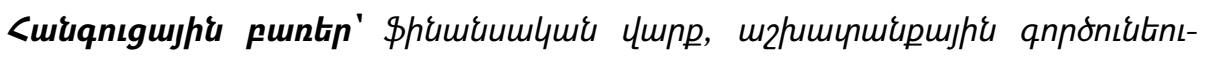

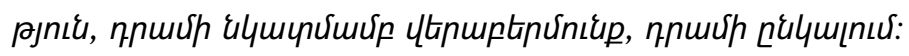

